\title{
MANAGEMENT OF VILLAGE PRIVATE ENTERPRISES AS AN ACCOMPLISHMENT OF THE INDEPENDENCE ECONOMIC VILLAGE
}

\author{
Masiyah Kholmi', Ahmad Waluya Jati' ${ }^{2}$, Diding Suhardi ${ }^{3}$ \\ University of Muhammadiyah Malang
}

\begin{abstract}
This research aims to describe the governance of Village-Owned Business Entities in Megaluh, Jombang. Data collection with questionnaires and documents. This research method using quantitative-descriptive. The results show that BUMDES in Megaluh was implemented with the purposes of BUMDES and increase the economics of the village. But there are several limitations in the governance of BUMDES, which is the educational background of the management of BUMDES governance was occupied by high school or vocational school graduates $(56,1 \%)$, the majority of BUMDES characteristics are in the form of savings and loans (56,4\%), trade (29,6\%), rental $(6,3 \%)$, and else (7,7\%). BUMDES does afford to contribute to village cash or PADes of the still low $(2,39 \%)$.
\end{abstract}

Keywords: BUMDes, independent village, management

\section{INTRODUCTION}

Rural development is a step for the government to develop Indonesia from the periphery with strengthening regions and villages as the subject of development and also participating in national development. Based on Government Regulation Number $60 / 2014$, the priority of the use of village funds is for the development and empowerment of rural communities. Ministry of Village, Acceleration Development Backward Regions and Transmigration sets priorities for development activities and empowerment of rural communities, therefore village institutions is need for support the implementation of the Village Program from Government in other to enhance independence village. Village institutions must work in synergistic and integrated manner to achieve independent, prosperous and participatory villages. Independent villages need relationships and cooperation with other villages of third 
Management of .......... (Masiyah Kholmi ${ }^{1}$, Ahmad Waluya Jati ${ }^{2}$, Diding Suhardi ${ }^{3}$ )

parties and all parties in developing their villages (Hamzah, 2015: 28).

In developing the village economy, Central Government give mandates to the Village Government authorize to manage development of the village through finance institutions independently such as Badan Usaha Milik Desa (BUMDes) (Budiono, 2015). The establishment of BUMDes is intended to accommodate economic activities managed by the Village or collaborate between Villages, this is in accordance with the statement from Permendesa No. 4 of 2015, Chapter II, Article 2. Increasing the income of the village community and Village Original Income is one of the objectives of establishing BUMDes.

In general, there has not been much research on the management of Village-Owned Enterprises because this topic is relatively new. Several studies related to the management of BUMDes have been carried out by Ridlwan (2014) who examine the nation's economic development through strengthening BUMDes. The results of the study indicate that the establishment and basis of BUMDes activities must be based on professional governance with reference to the guidelines for establishing BUMDes. Agunggunanto, et al. (2016) explained that there are several obstacles in managing the BUMDes, namely the limited type of business, human resources and the level of community participation is still low. The results of Purnamasari's study, et al. (2016) show that BUMDes have not been able to empower and improve the economy of their village communities. In achieving its objectives, management of BUMDes is still not effective and efficient. In terms of integration, management of BUMDes community involvement in participating in deliberation forums is limited to hamlet heads and does not involve the community at large.

BUMDes in Jombang have established since 2015, but there are still inequalities and have not utilized the maximum potential of the village. The Chairman of Commission A of the 
Management of ........... (Masiyah Kholmi ${ }^{1}$, Ahmad Waluya Jati² ${ }^{2}$, Diding Suhardi ${ }^{3}$ )

Jombang Regency DPRD said that the function of BUMDes was to improve the economy of rural communities, but in Jombang, BUMDes were only used to loan and fund activities (Faktualnew, 2017).

The existence of BUMDes in Jombang Regency is expected to be able to stimulate and drive the economy in the countryside in strengthening the economy of rural communities. Through the village government the community is motivated, based and prepared to build their own lives. This is needed in managing BUMDes to improve the ability to administer the Government and increase people's income towards independent villages.

Based on the above phenomenon, in the study of the management of Village-Owned Enterprises, it was intended to describe the management of BUMDes in the Megaluh sub-district of Jombang in the direction of an economically independent village. The method used is descriptive quantitative method.

\section{RESEARCH METHODS}

This research is a quantitative research with descriptive method. According to Nuryaman, et al. (2015), descriptive research aims to obtain an overview of certain characteristics (certain variables) of a subject that are of concern in the research activity. The research subjects were people who knew and were directly involved with the subject matter of the research focus. People who are directly involved such as managers (Directors) of VillageOwned Enterprises. This research is located in Megaluh District, Jombang Regency. In Jombang there are 21 subdistricts and subdistricts, there are 13 villages. The data collection technique used is the distribution of questionnaires and documentation in the form of BUMDes financial reports.

Data analysis was using descriptive quantitative analysis. Based on the data obtained, researcher describe field data systematically, accurately, and factually. Quantitative techniques will use percentage analysis that aims to provide an overview of the 
Management of .......... (Masiyah Kholmi ${ }^{1}$, Ahmad Waluya Jati ${ }^{2}$, Diding Suhardi ${ }^{3}$ )

conditions generally, it will conclude on existing data.

\section{RESULT AND DISCUSSIONS \\ Definition of Zakah as Tax Credits}

Village-Owned Enterprises

(BUMDes) are business entities established by the Village Government with initial capital from the Village Government. BUMDes aims to improve the welfare of the village community and foster the social capital of the village community. Therefore, BUMDes must be managed with competent and professional human resources and fulfill good corporate governance, namely participation, accountability, transparency and fairness. In the management of BUMDes, complete organization must be prepared in the form of Articles of Association, Bylaws, organizational administration and financial administration.

Based on the results of the questionnaire and documentation of Village-Owned Enterprises in Megaluh Sub-district consisting of 13 BUMDes, respondents stated that the organization form of BUMDes was determined based on Village Regulation (Perdes). The vision, mission and objectives of the Village Owned Enterprises are as follows:

1. The BUMDes vision is to improve the welfare of rural communities, build a village economy, and towards independent BUMDes.

2. The BUMDes mission is to increase the income of rural people, and Village Original Income, develop community businesses, facilitate the circulation of goods and services needed by the community, eradicate the practice of bondage and moneylenders.

3. The purpose of BUMDes is to improve the village economy, optimize village assets, improve community business, open employment opportunities, empower the economy of the community, encourage the development of economic activities in rural communities, create opportunities and market networks, 
Management of .......... (Masiyah Kholmi ${ }^{1}$, Ahmad Waluya Jati ${ }^{2}$, Diding Suhardi ${ }^{3}$ )

and reduce unemployment in the village. The purpose of the BUMDes was derived from the Vision and Mission of Village-Owned Enterprises in Megaluh Sub-District, Jombang Regency as stated in the Regulation of the Minister of Village, Republic of Indonesia Disadvantaged and Transmigration Number 4 of 2015, Chapter II, Article 3 concerning Establishment of BUMDes.

Related to human resources, based on data obtained from 12 BUMDes in Megaluh Subdistrict, the majority of education respondents (56.1\%) were high school / vocational school. Respondents who had a Bachelor level of education (S1) were 35 people $(35.7 \%)$ and only 2 respondents (3.1\%) had S2 education. While there are still 2 junior high school education levels. In general, the education level of BUMDes managers is still low (see figure 1), this result is strengthened by his research Agunggunanto, et al (2016); Purnamasari, et al (2016). BUMDes still face obstacles related to human resource capacity. This will be related to the capacity of the village's human resources in managing BUMDes, especially the BUMDes finances, with programs that should be carried out to encourage the development of BUMDes.

\section{Figure 1 Respondent's Education} Education profile

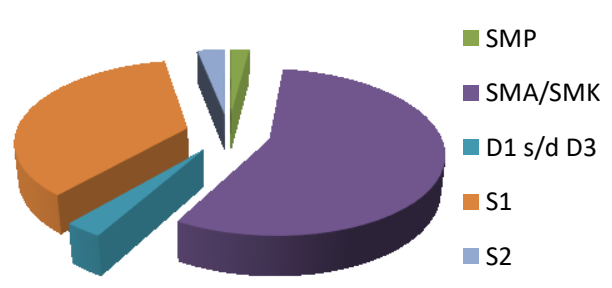

The BUMDes human resources are seen from the age of the manager, the data obtained from the majority field (Village-Owned Enterprises), age of respondents (44\%) are aged $41-50$ years, $23 \%$ are aged $31-40$ years. Respondents who have less than 30 years of age $13 \%$ and more than $51-60$ years are $16 \%$ and 4 respondents (4\%) have more than 61 years of age). The data can be seen in the picture as follows: 
Management of .......... (Masiyah Kholmi ${ }^{1}$, Ahmad Waluya Jati ${ }^{2}$, Diding Suhardi ${ }^{3}$ )

Figure 2 Age of BUMDes Managers

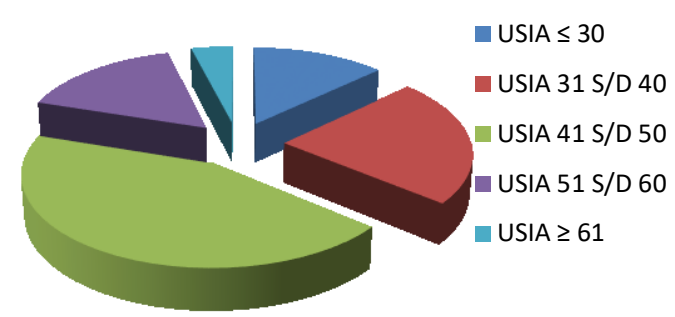

Characteristics of Business BUMDes

BUMDes are formed based on the Village Minister's Regulation, Development of Disadvantaged Regions, and Transmigration and Village Regulations concerning the Establishment of BUMDes (Permendes, No. 4 of 2015). The form of BUMDes is adjusted to the agreements formed in the village community. Thus, the type of business in accordance with the potential of the village and the needs of the community and does not cause economic distortions in the rural areas is due to businesses activity by BUMDes.

Based on collected data from respondents (13 BUMDes) in Megaluh
Subdistrict, 1 (one) BUMDes did not provide answers on the type of business, namely BUMDes Sri Kandi. The data obtained from the 12 BUMDes fields are mostly businesses in savings and loan units (45.5\%), in trading units $(22.7 \%)$, in rental units (18.2\%), and other units (13.6\%). The majority of business units in the Megaluh sub-district BUMDes are savings and loan units (see Figure 3). If referring to Permendes Regulation No. 4 of 2015, the classification of BUMDes business types includes: social business (providing public services), utilizing local resources and appropriate technology (such as drinking water business, electricity payment business, provision of food storage), rental business (such as transportation equipment, party equipment, meeting buildings, brokering, trading business and financial business. This shows that in general the development of the BUMDes business unit is already good, because it is not only dominated by savings and loan units. 
Management of .......... (Masiyah Kholmi ${ }^{1}$, Ahmad Waluya Jati ${ }^{2}$, Diding Suhardi ${ }^{3}$ )

\section{Figure 3 Characteristics of Business BUMDes}

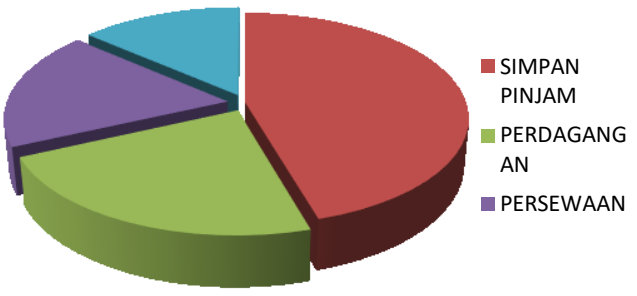

Based on the four characteristics of the BUMDes business, business turnover per month can be described from 8 BUMDes and 5 BUMDes were not provide information on business turnover data. Based on data obtained from the field, the majority of savings and loan units (see Figure 4) amounted to IDR 29,591,394 (74.2\%), rentals were IDR $7,864,005(19.6 \%)$, trading was IDR $1,747,416(4.3 \%)$, and others of IDR $750,000(1.9 \%)$. It can be concluded that the acquisition of BUMDes business turnover per month (data processed in September 2018) is relatively low. Thousands of BUMDes in Indonesia have not grown as expected, because BUMDes is an institution that can be said to be relatively new since the enactment of Village Law No. 6 of 2014 concerning Villages. The development of BUMDes requires several things, including: human resource potential, village potential, capital. Budiono (2015) mentions that of the 419 BUMDes in Bojonegoro Regency, only 21 BUMDes were still running and in the study, also found that BUMDes that were considered successful had also not been able to contribute to village cash revenues or PADes.

\section{Figure 4 Business Turnover of} BUMDes Per Month

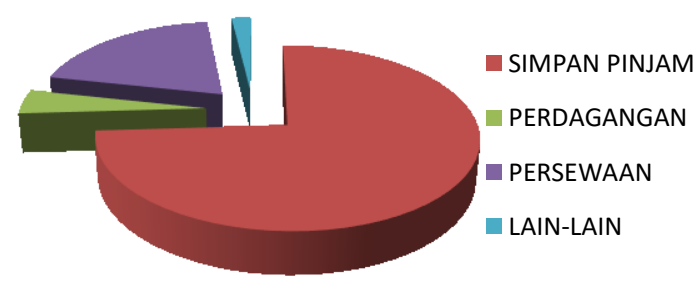

\footnotetext{
Village Government Equity Participation

Initial capital participation from the village government per villageowned business entity amounted to IDR
} 
Management of .......... (Masiyah Kholmi ${ }^{1}$, Ahmad Waluya Jati ${ }^{2}$, Diding Suhardi ${ }^{3}$ )

100.000.000 was disbursed starting in 2015. Based on data obtained from the field of 12 BUMDes. One of Bumdes did not fill their capital participation. The use of the highest capital participation in the total savings and loan unit on BUMDes in Megaluh District (see Figure 5) is IDR $954.700 .700 \quad(56,4 \%$ on average), trading is IDR 501.301.300 (average $29,6 \%$ ). Others amounted to IDR 129.593.500 (average 7,7\%), and the lowest use of capital participation in the rental unit was IDR 106.450.000 (average 6,3\%).

Figure 5 Use of Equity Participation from The Village Government

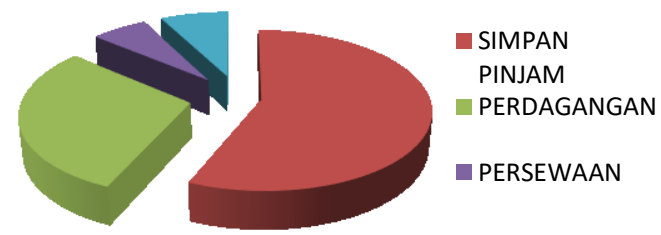

\section{Distribution of SHU}

From the 13 respondents, 12 respondents filled in the distribution of SHU in 2017. The answers of 12 respondents about the distribution of
SHU were grouped into 7 components. Data obtained from the majority field for the village cash component (Figure 6) amounted to IDR 28.616.247 (average 26\%), operational IDR 21.450 .667 (average 19\%), Reserves IDR 18.267.397 (average $16 \%$ ), Additional business capital of IDR $17.462 .426 \quad(15 \%$ on average), Education and social matters amounting to IDR 14.147.804 (average $13 \%$ ), Supervisor of IDR 6.431.939 (average 6\%), advisor amounting to IDR 5.079.981 (average 5\%). Based on the provisions of the distribution of SHU as in Table 1 below:

\section{Table 1 Distribution of Remaining Operating Results}

\begin{tabular}{lcc}
\hline \multicolumn{1}{c}{$\begin{array}{c}\text { Remaining } \\
\text { Operating Results }\end{array}$} & Provisions & Realized \\
\hline Added business & $30 \%$ & $15 \%$ \\
capital & & \\
$\begin{array}{l}\text { Regional original } \\
\text { income / Village Cash }\end{array}$ & $20 \%$ & $26 \%$ \\
$\begin{array}{l}\text { Advisory } \\
\text { Supervisor }\end{array}$ & $5 \%$ & $5 \%$ \\
$\begin{array}{l}\text { BUMDes Operations } \\
\text { Education and social }\end{array}$ & $25 \%$ & $6 \%$ \\
$\begin{array}{l}\text { Reserve } \\
\text { Total }\end{array}$ & $10 \%$ & $13 \%$ \\
\hline
\end{tabular}


Management of .......... (Masiyah Kholmi ${ }^{1}$, Ahmad Waluya Jati ${ }^{2}$, Diding Suhardi ${ }^{3}$ )

Figure 6 Distribution of SHU

PEMBAGIAN SHU TAHUN 2017

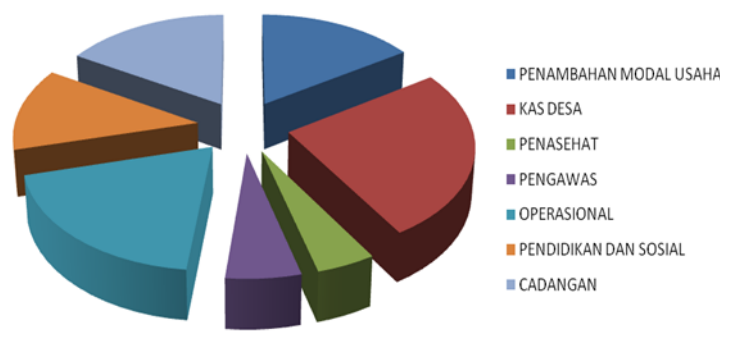

Based on the calculations in

Table 1 , the results of the study show that the funds for additional business capital and operational BUMDes are smaller than the provisions. The funds from the village treasury and the reserve fund are higher. The provisions for distributing the remaining proceeds of the business have not yet been standardized among BUMDes in Jombang Regency. seen from the number obtained by SHU in 2017 is relatively small, the total acquisition of SHU from 12 BUMDes that answered the question amounting to IDR 111.456.461 for 12 BUMDes, means that the average SHU per BUMDes amounted to IDR $8.868 .939,92$. This shows the acquisition of SHU BUMDes in the category still low at $8.87 \%$ of the initial capital of IDR 100.000.000,00.

\section{CONCLUSIONS}

BUMDes as an activity institution in the field of economy and / or public services managed by the Village and / or inter-Village cooperation. BUMDes activities are based on local characteristics, community needs and village potential, so as not to cause economic irregularities in rural areas due to businesses run by BUMDes. The objectives of the BUMDes implementation include increasing the income of the village community and the village's original income.

The management of BUMDes in Megaluh Subdistrict has been running according to the purpose of establishing BUMDes, namely improving the village economy. However, in the management of BUMDes there are still obstacles, such as most of the BUMDes managers have high school / vocational education. The characteristics of business turnover 
Management of ........... (Masiyah Kholmi ${ }^{1}$, Ahmad Waluya Jati² ${ }^{2}$, Diding Suhardi ${ }^{3}$ )

mostly in savings and loan units and the ability of BUMDes to contribute to the income of village cash or PADes is still low.

\section{REFERENCES}

Agunggunanto, E.Y. dkk. 2016. Pengembangan Desa Mandiri melalui Pengelolaan Badan Usaha Milik Desa (BUMDes), Jurnal Dinamika Ekonomi dan Bisnis, Vol 13, No.1.

Budiono, Puguh. 2015. Implementasi Kebijakan Badan Usaha Milik Desa (Bumdes) di Bojonegoro (studi di Desa Ngringinrejo Kecamatan Kalitidu dan Desa Kedungprimpen Kecamatan Kanor). Jurnal Politik Muda, Vol.4 No. 1, Januari - Maret, 116-125.

Hamzah, Ardi. 2015. Tata Kelola Pemerintahan Desa, menuju Desa Mandiri, Sejahtera, dan partisipatoris. Pustaka, Surabaya.

Nuryaman dan Veronica Ch. 2015. Metodologi Penelitian Akuntansi dan Bisnis. Ghalia Indonesia. Cetakan ke Satu. Indonesia.

Purnamasari, H, Eka, Y dan Rachmad R. .2016. Efektivitas Pengelolaan Badan Usaha Milik Desa Berbasis ekonomi kerakyatan di desa, warung bamboe kecamatan Karawang Timur kabupatan Kawarang, Jurnal Politikom Indonesia Vol. 1 No. 2 e-ISSN, 2582- 2069.
Peraturan Menteri Desa, Pembangunan Daerah Tertinggal, dan Transmigrasi Republik Indonesia Nomor 4 Tahun 2015 Tentang Pendirian, Pengurusan dan Pengelolaan, dan Pembubaran Badan Usaha Milik Desa.

Peraturan Daerah Kabupaten Jombang Nomor 3 Tahun 2013 tentang Pedoman Tata Cara Pembentukan dan Pengelolaan Badan Usaha Milik Daerah.

Ridlwan, Zulkarnain. 2014. Urgensi Badan Usaha Milik Desa (Bumdes) dalam Pembangun Perekonomian Desa. Fiat Justisia Jurnal Ilmu Hukum Volume 8 No. 3 Juli-September. ISSN 19785186.

Peraturan Pemerintah RI Nomor 60 Tahun 2014 tentang Dana Desa Yang bersumber dari Anggaran Pendapatan dan Belanja Negara

...... Undang-Undang No. 6 Tahun 2014 tentang Desa.

...... Bumdes di Jombang Amburadul. https://faktualnews.co. Tanggal akses 25 Oktober 2018.

Komite Nasional Kebijakan Governanace. 2006. Pedoman Umum Good Corporate Governance (GCG) Indonesia. Jakarta.

Pusat Kajian Dinamika Sistem Pembangunan. 2007. Buku Panduan Pendirian dan Pengelolaan Badan Usaha Milik Desa. Departemen Pendidikan Nasional. Fakultas Ekonomi. Universitas Brawijaya. 